\title{
The organizational culture of innovative schools: \\ The role of the Principal
}

\author{
Juan Carlos Riveras-León`, Marina Tomàs-Folch
}

\begin{abstract}
Social and technological changes demand constant updating, this implies that schools must be prepared to face these changes. As a result, they need to have the capacity to innovate as part of their organizational culture. Although it is true, that not all schools are examples of innovative organizations, it is possible to identify some that have a more innovative organizational culture than others. In the generation of that capacity, the principal's leadership plays an essential role, they are ones called to face the challenge of developing competences and skills to lead the change. Existing research confirms the importance of the school's leadership in the development of educational centers, OECD reports already ratified this, stating how vital it is to have good principals to lead schools (2009). In this study, schools have been chosen that have certain characteristics that are considered stand out for the Chilean educational system. By applying a questionnaire, the innovative potential of the centers being studied and their organizational culture to favor this are analyzed, the latter from the point of view of the principal's actions. The results allow confirming the innovative potential the studied centers have, the most substantial practices of the principal's actions that favor innovation are identified, as well as the key role the principal's leadership plays within these centers. At the same time, questions arise that limit the development of certain innovative actions, such as, the search and pressure for results originated essentially from standardized testing, like SIMCE, which is applied in Chile.
\end{abstract}

Keywords: Leadership for innovation; Innovative schools; Organizational culture

\section{Introduction}

The social changes of the globalized world demand greater competences and challenges, which imply that school organizations must adapt themselves to this changing, demanding and challenging system. For this reason, it is necessary that school organizations have the capacity to innovate (Ramírez, García, \& Cruel, 2017), that this capacity is institutionalized, that it forms part of their culture (Rubia, 2018), and corresponds to a collective effort (Ruay \& Ferrada, 2017).

The key for a school that intends on having success, understanding this as achieving better educational results, is in the search for innovative solutions, modifying their practices (López-Vargas \& Basto-Torrado, 2010), be these pedagogical or organizational,

\footnotetext{
- PhD candidate in Education, Autonomous University of Barcelona (UAB), Spain, juanriverasleon@yahoo.es

- PhD, Professor at the Department of Applied Pedagogy, Autonomous University of Barcelona (UAB), Spain, marina.tomas@uab.cat
} 
transforming them into practices that directly and indirectly produce greater and better results. This implies that an institution which does not believe in or incorporate different ways of acting, adapted to the new demands, cannot be conceived today; this requires collective efforts and commitments, with a sense of community (Leithwood, 2009; Gairín, 2015), and not just mere decisions and individual adventures (Hargreaves \& Fullan, 2014).

Although it is true, that innovations are not the same for all institutions, as no schools are alike, even though they are in places with very similar external conditions, the people and their relationships make them all different from one another. As a result, it is not possible to state that a school is innovative if it replicates one or another strategy, but it is possible to identify certain characteristics or elements that allow recognizing them as innovative schools or schools that have a potential to be guided along a path towards innovation. In this setting, principals play a determining role, because the challenge of developing competences and skills to lead the change falls upon them (Fullan, 2014).

Different research confirms the importance of the principal in the development of a school ( Silva, Del Arco, \& Flores, 2018), The OECD points out how vital it is to have good principals, and suggests that governments select and prepare those who will emerge with the greatest capacity to direct schools (OECD, 2009).

On the other hand, it also says that educational quality is closely tied to the capacity of the educational institutions to foster changes..." (Tomás et al., 2009); what is fundamental is knowing: what is the innovation potential of these schools and how does this contribute to their development? Understanding innovation potential as the capacity to evaluate, integrate and disseminate innovation processes (Tomás et al., 2009). As a result, the answers found through this research help or guide how to answer certain questions: Which aspects of the organization culture favoring innovation can be references for other educational contexts? Which elements must be considered to develop innovation processes in schools?

This article looks to get to know the organizational culture of schools in the Region of Magallanes, Chile, with the goal of inquiring about the possibilities of generating innovation, led from the action of the schools' principals. What is outlined leads us to seek answers and opens more questions, such as: Which actions of the principals of schools in the study contribute to the generation of a successful organization and promotor of innovation? Which actions of the principal and of organizational culture block school innovation? Or beyond the schools, which public policies encourage generating innovative schools? Which public policies limit school innovation?

This work considers the following hypothesis: "the democratic and participatory leadership of the principal is fundamental in the generation of a school culture favorable to innovation". Where certain managerial practices, for example, the promotion of collaborative work among teachers favors their involvement with change actions, which leads to sustaining innovative processes over time. 


\section{Theoretical guidelines}

\section{The current challenges of schools}

Castells (2010) suggests that changes in education are key and must begin with a social commitment (Giroux, 2016) and that of the States, where the new organization and administration logic overcomes bureaucracy and that finally pedagogical innovation is achieved. As a result, educational institutions must be created where it is possible "to learn to learn". We outline the challenges schools have to face in the future, how these must be led to resolve the situations they are afflicted by and to collectively seek success, where the collaboration of teaching staff is essential to drive innovation processes in schools (Gairín, 2000; Hargreaves \& Shirley, 2012; Krichesky \& Murillo, 2018), even though this is not free from complexities, nor does it alone produce the desired effect of ensuring innovation and improvement.

The challenges and demands on educational systems today are enormous and these lead to aspirations of schools to respond to them. The school must take on these demands, and from this, many questions arise like: how to guarantee quality? What do you do to educate with quality and equality? What is the role of the school? How does the school organize to generate innovations that meet the social demands and challenges? Questions that must be answered, analyzed, reflected upon, jointly, from the institutional commitment. If we measure the quality today using the competences the students have or achieve in a given school, it is worth asking ourselves: are the quality demands the students need being met? Perhaps there are many answers, sometimes, to a greater or lesser extent, but surely, no school can guarantee an absolute yes.

\section{Characteristics of school organizations with effective practices}

The revision of the literature about the requirements of an educational organization to be effective, lead us to many coincidences: learning centered leadership, high expectations of the academic leadership (Schmelkes, 1998), the staff must be motivated and very committed, they must have proactive people, clear goals, a vision and mission that identifies them, develop people (Leithwood, 2009), collaborative work, continuous adaptation and development of the creativity considering the organization (Esteves, 2018; Hildreth \& Kimble, 2004).

Due to the ever-growing complexity of problems organizations have, it is necessary that learning is done in a team, as it has been shown that learning and ideas generated collaboratively are more creative, innovative and have a better quality than those generated by people individually (Hargreaves \& Shirley, 2012). This occurs, as by interacting in a team, allows contrasting mental models, perceptions, namely, opening up to contrasting the interpretations of the real world (León, Tejada, \& Yataco, 2014). With the employers interacting, even though they perform different roles, they tend to improve performance, which leads to substantial improvements for the organization (Gittell, Seidner, \& Wimbush, 2010). This becomes even more relevant nowadays where schools 
have the challenge of generating school inclusion policies (Gallager, 2013; Parrilla, Sierra, \& Fiuza, 2018).

\section{Educational Innovation}

Schools seek to innovate by transforming their practices, be these pedagogical or organizational, to convert these into practices that directly and indirectly produce greater learning achievements among the students. As a result, in the educational plane, one innovates to adapt, to better respond to society, to provide different solutions to real problems (Adams et al., 2017). Thus, to find answers, that lead the school organization to obtain improvements, a different way of doing things is a must, which implies making a change in the culture of the staff and in the roles of the institution's leaders (Santos, M. A. S., Jover, Naval, Álvarez, \& Sotelino, 2017).

The term "innovate" is commonly related to change. To understand the differences of the two concepts, it is worth citing Tomás et al. "innovation means changing towards something that is completely new or somewhat new compared to the innovation target. Not all change is innovation, but innovation always means change and implies a willingness that favors change" (Tomás et al., 2009, p. 6). Etymologically innovate means "introducing novelty into something", "moving or altering things".

For Tejada (2008), talking about educational innovation "implies an action that brings about the introduction of something new into the educational system, modifying its structures and operations so that improvements are made in its educational results" (p. 94). All the aforementioned definitions of innovation leave it clearly established that innovating always means improving. Here is where "innovation" emerges as the key to improve education (Cantón, Turrado-Sevilla, \& Santos-Lozano, 2017)

In summary, for this article, and using the aforementioned authors as reference, we will use the concept of educational innovation and the introduction of changes in the different processes; be these pedagogical, inclusive, administrative or promoters of healthy co-existence; that are done in the school and that necessarily produce an improvement for the institution, having positive repercussions, at the end of the day, on the education of students.

\section{Factors to consider in educational innovation}

So that an institution can end up being innovative, it must incorporate certain characteristics that foster and ground the guidelines to institutionalize innovation, incorporating these into the institutional culture, just as Krichesky \& Murillo (2018) mention: "staff collaboration is an essential condition to foster innovation and improvement processes in educational centers" (p. 135). An educational institution that seeks improvement, will try to form a learning community that collectively seeks innovative solutions. Schools have to have innovation, teamwork, the formation of a learning community, as a characteristic, where the members support each other. This will aid the task of innovating, where there are spaces for reflection, self-assessment and 
participation (Tejada, 2008). The pretensions of educational organizations must head in this direction, building teams with the due participation and collaboration of their members (Chaljub, 2010).

To create an innovative school, the first thing is being open to change. For this reason, the individualism that has characterized schools must be overcome. Motivation, communication and openness to new learning are key; "if the teachers act as a team, if they dialog, project and work as a community, if they are open to learning, they will enjoy their profession and will be more motivated to improve themselves" (Santos, 2001, p. 79). It is very relevant for the institutions to have personnel that are open to change, that constantly seek new ways to work. De la Torre says that "so that a problem becomes a principle of innovation and change, it is necessary that there are people with initiative, with concrete proposals and with a certain recognition among the teachers", cited by Tomás et al. (2009, p. 28). The relational system of a school plays a central role in this entire process, where once again, there are close ties with the leadership. Here is where the school's principal has a central role in the generation of a favorable climate for the school's culture, just as the different typologies of leadership mention (Blanchard, Blanchard, Zigarmi, \& Zigarmi, 1986; Wrigley, 2007).

For an action to have success, it is necessary to consider the environment and the context it will take place within. On not considering these elements, the intended innovations will just be a good idea, no different to many that start in organizations, especially in schools. There are programs that start up, but the limited planning, the lack of follow-up, the failure to evaluate weakens them, leaving them as a fruitless idea, one that began enthusiastically, but ends up dying away. All these good intentions die out and often leave more setbacks than creations. The members of the organization enter a state of skepticism about new projects, because they have an accumulated experience of failures leading them to think the same that happened before, will happen again. These initiatives are not always internal. The same happens with public policies led by different governments, which fall by the wayside or are replaced by other visions or new ideas. From this perspective, innovation processes, require being managed to reduce possibilities of failure, showing the role of the principal at the core of the improvement processes, facilitating team meetings, systematizing different actions, monitoring, evaluating and supporting a climate based on respect and professionalism (Crawford, 2012; Muijs \& Rumyantseva, 2014).

\section{Importance of leadership for innovative schools}

There is no doubt that the improvement of education quality in schools, among other factors, depends on the school principal they have (Northouse, 2004). Educational leadership is the most important internal factor of a school, to achieve student learning, after the teaching staff's teaching, according to the McKinsey (Barber \& Mourshed, 2008) and OECD reports (Pont, Nusche, \& Moorman, 2009). Therefore, looking deeper at further 
education and seeking the way to perform leadership actions, is crucial for better education in schools and as a result, educational systems.

School leadership is a pending task in current pedagogical leadership models (Bolívar, 2007). This phenomenon is characteristic of many educational systems, with the Chilean version being a very patent example of this. Fortunately, actions have strongly started developing, both nationally and internationally, that aim at giving school direction, the importance that it merits regarding the effect it has on educational results. OECD (2008) states, that school leaders exercise a measurable influence, mainly indirectly, over learning results. This means that the impact of school leaders on student learning, is generally measured by other people, events and organizational factors. As such, the principal's leadership contributes indirectly, creating the most suitable conditions for teaching processes, also affecting the people and the organization.

Leadership is very important for educational organizations, connected to the school principal, where the latter is key in the generation of an institution that is effective in achieving the improvements in educational quality that are sought today (Ríos, Maturana, Almonacid, Shink, \& Jaramillo, 2010). "Nobody doubts the importance of leadership for three situations: to facilitate change and innovation; to provide a vision of the organization; to encourage the first steps" (Bolívar, 2007, p. 17). Apart from the positive impact on student learning, starting from the principal's action, this can affect the transformation of the teaching practices (Day, Gu, \& Sammons, 2016), strengthening the work of the teachers (Bolívar, 2010). Furthermore, the leadership can be much more of a determining factor in schools in vulnerable and poverty contexts (Horn \& Marfán, 2010; Weinstein, 2009), which implies that leadership is crucial there to improve the quality of the teaching (Robinson, Hohepa, \& Lloyd, 2009).

\section{Method}

This article is a descriptive study of a quantitative nature, that seeks to get to know the innovation potential of schools, identifying the leadership actions of the principal that aim towards generating a school culture that favors innovation, getting to know the actions that allow the involvement of teachers in innovation and displaying the characteristic leadership style of the schools that have been recognized by the Ministry of Education with the Excellent Performance Grant in the Magallanes Region. A questionnaire is used as the tool to collect information.

\section{Construction and Validation of the Tool}

The instrument was designed with closed questions and a single scale, Likert type, for the entire instrument. Where option " 1 " corresponds to being "strongly in disagreement" with the statement made; "2" "disagree"; "3" "agree" and option "4" "strongly agree"; in this way, the bias of the response to the central alternative is avoided. The preparation was made from an exhaustive review of research related to the subject and about similar tools. Alongside this, the research goals, the choice of dimensions, the formulation of 
variables for each dimension and the later validation and filtering were defined, until obtaining the final version of the tool (Sierra, 2013). The structure of the questionnaire includes in the first part, the data on the characterization of the sample. Then it considers various variables grouped into the following topics: innovation potential; managerial influence, managerial importance in innovation; leadership styles and institutional leadership practices.

To validate the questionnaire, to generate greater quality, expressed in the validity and reliability of the items, two fundamental procedures were considered: the judgment of experts and statistical analysis made based on a pilot test (Osterlind, 1989). The first validation step was studying the content using the judgment of experts, a procedure often used in this type of filtering (Barroso \& Cabero, 2010). It was sought to determine, in this way, whether the 86 variables of the tool cover the content that is sought to be measured (Ruiz, 2002). For the first case, once the tool was developed, it was sent to 10 judges chosen on being expert researchers in research method and professionals with knowledge on the administrative and organization context of the schools under study, including academics from Chilean and Spanish universities, civil servants from the Ministry of Education and outstanding teachers from the Chilean education system, 8 of whom generated their reports. The revision of each evaluator was made regarding univocality, pertinence and importance regarding the goal. 12 items were eliminated as a result of this first validation, another 12 were modified and 1 was set in another goal.

Later the tool was applied in a pilot test to 166 teachers to make an internal consistency test of the questionnaire. The Cronbach coefficient was used for this, through the SPSS statistical program. For this case in particular, after having removed 8 items, a Cronbach Alpha reliability of 0.877 was obtained. After the construction and filtering of the tool, it was applied in this work.

\section{Population and Sample}

The questionnaire was applied to teachers belonging to schools that have been recognized by the National Performance Evaluation System of educational establishments subsidized by the State, whose acronym is SNED, of schools in the Magallanes region, Chile. The schools that are best evaluated by this System become creditors, for two years, of the Excellence Performance Grant designed to grant remuneration incentives to teachers and paraeducators. In accordance with current regulations, a SNED performance index of schools is calculated, based on the measurement of six factors: Effectiveness, Improvement, Initiative, Improvement of working conditions, Equal opportunities, and Integration and participation.

From the total population, corresponding to 611 teachers, a probabilistic representative sample was taken, of a stratified type, considering as strata: socioeconomic level of the students they attend; seniority of teachers in schools; urbanrural schools and their enrollment. For which, the proportional calculations of elements that are required of each stratum were made to respond to the representativeness of the 
population under study, applying the instrument to a population of 186 teachers, obtaining a response of 126 teachers, equivalent to $20.6 \%$ of the total population.

\section{Results}

\section{Characterization of the Sample}

According to gender, $66.7 \%$ correspond to women and 33.3 to men; $74.6 \%$ of the teachers belong to urban schools and $25.4 \%$ to rural ones; $80.2 \%$ belong to public (municipal) schools and $19.8 \%$ to private schools, but which receive funding from the State; $100 \%$ of the teachers have a degree in education; the average age is 41.1 years; $42.9 \%$ have a bachelor's degree as the maximum academic degree and 9.5\% a master's degree, none of the participants has a doctorate; They have been working in the same school for an average of 9 years and the average age is 41.2 years.

\section{Innovative potential of the studied schools}

The first items of the questionnaire look to identify the "innovative potential" of the schools being studied. The overall result for the set of items has an average of 3.13, expressing being "in agreement" with the claims that imply having an "innovative potential". If it is observed by the areas the questions are structured into, it can be seen that they all have a high valuation, where the lowest is the "diagnosis" with 3.03 and "integration of innovation" with 3.05. The standard deviations of the items are minimal which shows a low spread of responses, as a result, there is a very similar perception of the teachers who answered the questionnaire.

Table 1. Total Sample Innovative Potential

\begin{tabular}{lccc}
\hline Items Average & \multicolumn{2}{c}{$\mathbf{N}$} & $\begin{array}{c}\text { Mean of } \\
\text { Valid }\end{array}$ \\
\hline "Diagnosis" & 118 & 8 & 3.03 \\
“Definition of Problems & 125 & 1 & 3.21 \\
"Planning of Solutions & 125 & 1 & 3.16 \\
“Closing of Plans & 120 & 6 & 3.20 \\
“Assessment of Results & 124 & 2 & 3.13 \\
"Integration of & 124 & 2 & 3.05 \\
$\begin{array}{l}\text { Innovation" } \\
\text { "Projection of }\end{array}$ & 125 & 1 & 3.18 \\
Innovation & & & \\
Overall Result & $\mathbf{1 1 8}$ & $\mathbf{8}$ & $\mathbf{3 . 1 3}$ \\
\hline
\end{tabular}

Source: SPSS Statistics

\section{Relationship of "innovative potential" variables}

The Pearson Correlation Test was run to see the relationships between the different variables that measure innovative potential, analyzing the following variables: "diagnosis 
of the innovation", "integration of innovation", "projection of innovation", and "assessment of results".

Table 2. Correlations of Variables

\begin{tabular}{|c|c|c|c|c|c|}
\hline & & "Innovati & & & \\
\hline & & $\begin{array}{c}\text { ve } \\
\text { potential } \\
\text { diagnosis } \\
\text { " }\end{array}$ & $\begin{array}{c}\text { “Integrati } \\
\text { on of } \\
\text { innovatio } \\
\text { n }\end{array}$ & $\begin{array}{c}\text { “Projecti } \\
\text { on of } \\
\text { Innovatio } \\
\text { n }\end{array}$ & $\begin{array}{c}\text { “Assessme } \\
\text { nt of } \\
\text { Results }\end{array}$ \\
\hline $\begin{array}{l}\text { "Innovative potential } \\
\text { diagnosis }\end{array}$ & $\begin{array}{l}\text { Pearson } \\
\text { Correlation }\end{array}$ & 1 & $.360\left(^{* *}\right)$ & $.230\left(^{*}\right)$ &.$(* *)$ \\
\hline & $\begin{array}{l}\text { Sig. } \\
\text { (bilateral) }\end{array}$ & & .000 & .012 & .001 \\
\hline & $\mathrm{N}$ & 118 & 118 & 118 & 118 \\
\hline $\begin{array}{l}\text { "Integration of } \\
\text { Innovation" }\end{array}$ & $\begin{array}{l}\text { Pearson } \\
\text { Correlation }\end{array}$ & $.360\left(^{* *}\right)$ & 1 & .118 & $.369\left(^{* *}\right)$ \\
\hline & $\begin{array}{l}\text { Sig. } \\
\text { (bilateral) }\end{array}$ & .000 & & .193 & .000 \\
\hline & $\mathrm{N}$ & 118 & 124 & 124 & 124 \\
\hline $\begin{array}{l}\text { "Projection of } \\
\text { Innovation" }\end{array}$ & $\begin{array}{l}\text { Pearson } \\
\text { Correlation }\end{array}$ & $.230\left(^{*}\right)$ & .118 & 1 & $.190\left(^{*}\right)$ \\
\hline & $\begin{array}{l}\text { Sig. } \\
\text { (bilateral) }\end{array}$ & .012 & .193 & & .034 \\
\hline & $\mathrm{N}$ & 118 & 124 & 125 & 124 \\
\hline $\begin{array}{l}\text { "Assessment of } \\
\text { Results" }\end{array}$ & $\begin{array}{l}\text { Pearson } \\
\text { Correlation }\end{array}$ & $.305\left(^{* *}\right)$ & $.369(* *)$ & $.190\left(^{*}\right)$ & 1 \\
\hline & $\begin{array}{l}\text { Sig. } \\
\text { (bilateral) }\end{array}$ & .001 & .000 & .034 & \\
\hline & $\mathrm{N}$ & 118 & 124 & 124 & 124 \\
\hline
\end{tabular}

** The correlation is significant at the 0.01 level (bilateral).

* The correlation is significant at the 0.05 level (bilateral).

The table above shows us a significant correlation at a level of $<0.05$ regarding "projection of innovation" and a significant correlation to $<0.01$ regarding the rest of the variables. Therefore, the results show that, when innovation is assessed, the institution is also included, is projected and the results are assessed.

Relationship between the "innovative potential" and the "actions of an organizational culture that is favorable for innovation"

The Pearson correlation calculation has been made to determine the correlation there is between the variables "innovative potential" and "actions of an organization culture that is favorable for innovation". 
As seen in the following table, there is a high correlation between the two variables, at a level of $>0.01$, which is why it can be confirmed that there if there is an innovative potential, there are also practices of the organizational culture that favor innovation in these schools.

Table 3. Correlations of Variables

\begin{tabular}{|c|c|c|c|}
\hline & & $\begin{array}{c}\text { Innovative } \\
\text { Potential } \\
\text { (General) }\end{array}$ & $\begin{array}{c}\text { Leadership } \\
\text { practices } \\
\text { favoring } \\
\text { innovation } \\
\text { (General) }\end{array}$ \\
\hline \multirow{4}{*}{$\begin{array}{l}\text { Innovative } \\
\text { Potential } \\
\text { (General) }\end{array}$} & Pearson & \multirow{3}{*}{1} & \multirow{2}{*}{$.449\left(^{* *}\right)$} \\
\hline & Correlation & & \\
\hline & Sig. (bilateral) & & .000 \\
\hline & $\mathrm{N}$ & 116 & 105 \\
\hline $\begin{array}{l}\text { Leadership } \\
\text { practices favoring }\end{array}$ & $\begin{array}{l}\text { Pearson } \\
\text { Correlation }\end{array}$ & $.449\left(^{* *}\right)$ & \multirow[t]{2}{*}{1} \\
\hline innovation & Sig. (bilateral) & .000 & \\
\hline (General) & $\mathrm{N}$ & 105 & 113 \\
\hline
\end{tabular}

\section{Influence of the principal in the involvement of teachers with innovation}

Regarding the dimension, "influence of the principle in the involvement of teachers with innovation", it can be seen through the results of the questionnaire, that leadership actions like: "valuation of the staff", "promotion of a good working environment", "stimulation of collaborative work" and "principle's action is example of commitment", favor the involvement of teachers.

Table 4. Means of Highlighted Variables

\begin{tabular}{lcccc}
\multicolumn{1}{c}{ Variables } & & $\mathbf{N}$ & $\begin{array}{c}\text { Mean } \\
\text { of } \\
\text { Valid }\end{array}$ & $\begin{array}{c}\text { Stand. } \\
\text { Dev. } \\
\text { Lost }\end{array}$ \\
\hline $\begin{array}{l}\text { "Valuation of the staff } \\
\text { "Promotion of a good working }\end{array}$ & 126 & 0 & 3.37 & .635 \\
$\begin{array}{l}\text { Lnvironment" } \\
\text { "Stimulation of collaborative work" }\end{array}$ & 126 & 0 & 3.27 & .698 \\
$\begin{array}{l}\text { "Principle's action is example of } \\
\text { commitment }\end{array}$ & 122 & 4 & 3.18 & .643 \\
"Clear information for everyone" & 124 & 2 & 3.29 & .609 \\
\hline \multicolumn{1}{c}{ Source: SPSS Statistics } & & 0 & 3.08 & .744 \\
\hline
\end{tabular}




\section{Relationship of "democratic leadership" with "principal's influence in the involvement of teachers with innovation"}

On making the Pearson Correlation Test for the variables "democratic leadership of the Principal" and "principal's influence on teacher involvement", we find a statistically significant correlation, with a coefficient ( $r=.000$ and $p=117$ ) as shown in the table, which allows stating that the actions of a democratic leadership style favor the involvement of teachers with innovation.

Table 5. Correlation of Variables

\begin{tabular}{|c|c|c|c|}
\hline Variables & & $\begin{array}{l}\text { Democratic } \\
\text { Leadership }\end{array}$ & $\begin{array}{l}\text { Principal's } \\
\text { influence in } \\
\text { teacher } \\
\text { involvement } \\
\text { (General) }\end{array}$ \\
\hline \multirow[t]{3}{*}{ Democratic Leadership } & $\begin{array}{l}\text { Pearson } \\
\text { Correlation }\end{array}$ & 1 & $.620\left(^{* *}\right)$ \\
\hline & Sig. (bilateral) & & .000 \\
\hline & $\mathrm{N}$ & 122 & 117 \\
\hline \multirow{3}{*}{$\begin{array}{l}\text { Principal's influence in } \\
\text { teacher involvement } \\
\text { (General) }\end{array}$} & $\begin{array}{l}\text { Pearson } \\
\text { Correlation }\end{array}$ & $.620(* *)$ & 1 \\
\hline & Sig. (bilateral) & .000 & \\
\hline & $\mathrm{N}$ & 117 & 119 \\
\hline
\end{tabular}

\section{Importance assigned by teachers to principals in the generation of innovation}

The opinion of teachers from the studied schools, gives great importance to the principal, as the variables "recognition of the community of the principal's action" and "the importance of the principal's action for innovation", have means of 3.22 and 3.27 respectively, marks that are between "agree" and "strongly agree" in the statements.

Means of the Variables

Table 6. Means of the Variables

\begin{tabular}{|c|c|c|c|c|}
\hline \multirow[b]{2}{*}{ Variables } & \multicolumn{2}{|c|}{$\mathbf{N}$} & \multicolumn{2}{|l|}{ Mean } \\
\hline & Valid & Loss & Lost & Dev. \\
\hline $\begin{array}{l}\text { "Recognition of the community of the } \\
\text { principal's action" }\end{array}$ & 125 & 1 & 3.22 & .633 \\
\hline $\begin{array}{l}\text { "Importance of the principal's action for } \\
\text { innovation" }\end{array}$ & 126 & 0 & 3.27 & .670 \\
\hline
\end{tabular}

Source: SPSS Statistics 
Relationship between "principal's influence in teacher involvement" with "importance of the principal for innovation".

On making the Pearson Correlation Test between the variables "principal's influence in teacher involvement" with the "importance of the principal for innovation", we find a statistically significant correlation, with a coefficient ( $r=.000$ and $p=116)$, which implies a statistically significant correlation of 0.01 .

Table 7. Correlations of Variables

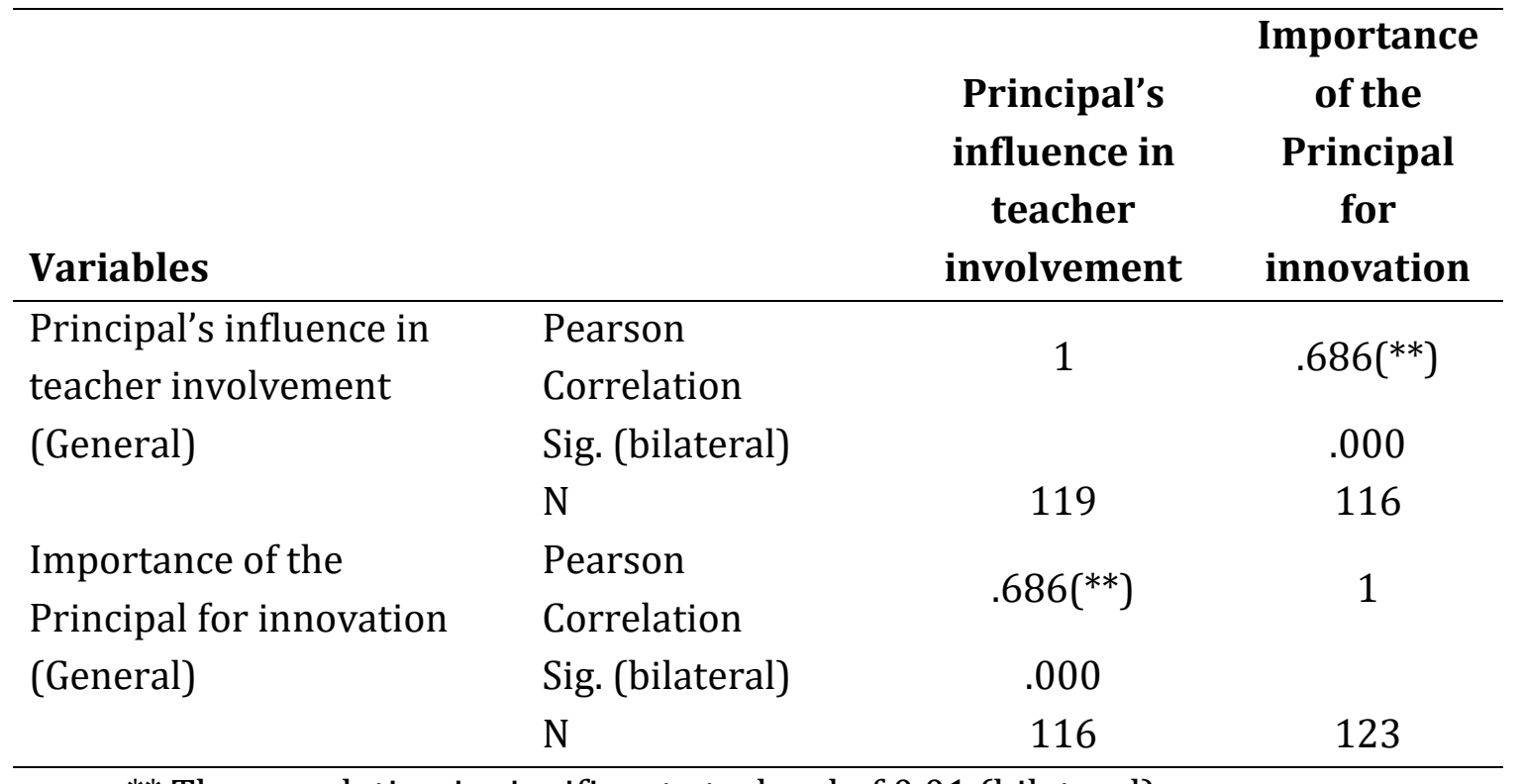

** The correlation is significant at a level of 0.01 (bilateral).

This shows us that, the importance that teachers assign to the school's principal, is directly related with the influence the school's principal exercises in teacher involvement in innovation.

Leadership practices that contribute to instilling an organizational culture that is favorable for innovation

The questions of this section of the questionnaire look to identify leadership practices that have contributed to instilling an innovation culture. Among the principal's practices and the organizational culture that have the greatest presence in the studied schools, are: "stimulating institutional environment", "promotion of new teaching practices", "conviction to make the changes that are required", "focus on student learning", "planning meetings", "identification with the institution", "meetings with opportunities for reflection", "further education for staff", "management of external resources". All the variables with means over 3.20. 


\section{Correlations between Variables}

Table 8. Correlations between variables

\begin{tabular}{|c|c|c|c|c|}
\hline \multirow[b]{2}{*}{ Variables } & \multicolumn{2}{|c|}{$\mathbf{N}$} & \multirow{2}{*}{$\begin{array}{c}\text { Mean } \\
\text { Valid Lost }\end{array}$} & \multirow{2}{*}{$\begin{array}{l}\text { Stand. } \\
\text { Dev. }\end{array}$} \\
\hline & Valid & Lost & & \\
\hline $\begin{array}{l}\text { "Responsibility facing achievements and } \\
\text { failures" }\end{array}$ & 123 & 3 & 3.14 & .605 \\
\hline "Stimulating institutional environment & 126 & 0 & 3.29 & .605 \\
\hline "Promotion of new teaching practices" & 125 & 1 & 3.33 & .669 \\
\hline $\begin{array}{l}\text { "Conviction to achieve the changes that } \\
\text { are required }\end{array}$ & 126 & 0 & 3.25 & .656 \\
\hline "Focus on student learning" & 126 & 0 & 3.37 & .576 \\
\hline "Identification with the institution" & 125 & 1 & 3.41 & .540 \\
\hline "Meetings are opportunities for reflection & 121 & 5 & 3.25 & .674 \\
\hline
\end{tabular}

Source: SPSS Statistics

\section{Discussion and conclusions}

The results of this work show with clarity, that the action of the principal is essential in the generation of an innovative organization. These results are similar to those obtained previously in several research projects in other contexts (Bolívar, 2007; Fullan, 2008; OECD, 2009; Ríos et al., 2010). The collaborative work entails a teacher involvement that contributes towards generating an organizational culture that favors, and a participative and democratic leadership is mainly related with an organizational culture that promotes innovation in schools.

The current theory aims towards these constructs, but it is necessary to check in a close and particular context that the findings of the research can be evidenced in a given context, with the pretension of setting examples for other schools that still are not driven to start innovation processes.

It is concluded that, the schools in the study have a high innovation potential, which does not imply that they are, but does confirm the presence of the basic elements to define that have the profile for it. Regarding the influence of the principal in teacher involvement with innovation, it is concluded that, the elements of the principal's action most valued by the teachers, are: feeling considered in decision-making, responsible and capable of assuming challenges; making them feel at all times that they are a core part of the institution; promoting collaborative work within the school in a healthy environment of co-existence; the valuation and consideration of opinions; the high expectations; the involvement of the principal; the emphasis on teaching and the constant motivation.

Regarding determining the importance assigned by teachers to principals in the generation of innovation, the results encourage concluding, that teachers think that the principal is key in the school's development and for driving innovation in the schools being studied. Regarding the leadership that principals exercise in the studied schools, it 
is concluded that the prevailing and most valued style corresponds to democratic characteristics, where dialog and participation in decision-making are fundamental.

Regarding the leadership practices that contribute towards instilling a culture of innovation, and that have a high valuation are: being responsible for results, the existence of clear goals, change management, the search for creative solutions, the vision that achievements are the result of collective efforts and the generation of opportunities for reflection.

Finally, some considerations that it is advisable to continue studying in greater depth from these results are: although it is true, it is conclusive to confirm that school innovation is needed to improve school equality and quality, to generate inclusion processes, to development transversal values among students, and to foster new methodologies. The principal's leadership in this task is also vital, but at the same time, and considering some educational systems, like the Chilean case, it is advisable to emphasis or at least suggest some questions like: what are the limitations for educational innovation? How can the incorporation of innovation processes affect the search and pressure from results in standardized tests like SIMCE? Are school principals prepared to lead, assume and handle change processes? Are suitable candidates being chosen to face this challenge? Which public policies are needed to encourage innovation processes? Is there a real concern of intermediary agents for authorities to promote change and innovation? As a result, different challenges emerge for the educational systems which can be investigated in more depth in later studies.

\section{Study limitations}

A limitation arises from the application of the instrument, since the results may have been affected, considering that giving an opinion on the management of the the staff is a sensitive issue, and that many times causes mistrust.

Another limitation emerges in the generation of variables, where with the intention of identifying the leadership styles within the study, new variables were generated by grouping different items of the questionnaire, therefore, an equivalent value of each of them is assumed, in circumstances that the weight of each one is different, which means that they should have a different weighting.

Also as a limitation of the study, in the construction of the instruments, it can be noted that, in the characterization of each leadership style, a reduced sample of particularities that define them was considered, even though they are the most important traits, there are other characteristics that were not considered.

The study covers directive management from the individualized point of view of the director, but directive management linked to the management team has emerged with great force. Even though in the application of the instruments it was explained that the referred study focused on the directors, on the responses of the informants, when thinking about the "directive action", it is possible that they linked it to the management team. 


\section{References}

Adams, S., Cummins, M., Davis, A., Freeman, A., Hall, C., \& Ananthanarayanan, V. (2017). NMC Horizon Report: 2017 Higher Education Edition. Austin, Texas, USA: The New Media Consortium.

Barber, M., \& Mourshed, M. (2008). Cómo hicieron los sistemas educativos con mejor desempeño del mundo para alcanzar sus objetivos. Retrieved from http://www.oei.es/pdfs/documento_preal41.pdf.

Blanchard, K. Z., Blanchard, K., Zigarmi, P., \& Zigarmi, D. (1986). El Líder Ejecutivo al minuto. Ciudad de México, México: Grijalbo.

Bolívar, A. (2007). Liderazgo, mejora y centros educativos. In El liderazgo en educación. Madrid, España: UNED.

Bolívar, A. (2010). ¿Cómo un liderazgo pedagógico y distribuido mejora los logros académicos? MAGIS, $3(5), 79-106$.

Cantón, I., Turrado-Sevilla, M., \& Santos-Lozano, A. (2017). Medida de innovaciones en escuelas de Educación Infantil y Primaria. Revista de Estudios y Experiencias en Educación, 16(32), 49-66.

Castells, M. (2010). Innovar la educación en la SIC. Presented in IV International Congress of Administration of Education, Staff and Education, ITC and Education, University of Costa Rica, Costa Rica.

Chaljub, J. (2010). Aprendo 2010. Presented in International Education Seminar, Pontificia Universidad Católica Madre Maestra, Santo Domingo, Dominican Republic.

Crawford, M. (2012). Solo and distributed leadership: Definitions and dilemmas. Educational Management Administration \& Leadership, 40(5), 610-620.

Day, C., Gu, Q., \& Sammons, P. (2016). The impact of leadership on student outcomes: How successful school leaders use transformational and instructional strategies to make a difference. Educational Administration Quarterly, 52(2), 221-258.

Esteves, D. (2018). Colaborar para innovar: Contribuciones desde un caso portugués para rediseñar la noción de innovación educativa. Revista Educación, Política y Sociedad, enero-junio, 7-30.

Fullan, M. (2008). Las claves del cambio en la escuela. El significado del cambio educativo. Santiago, Chile: MINEDUC.

Fullan, M. (2014). The principal. Three keys to maximizing impact. San Francisco, USA: Jossey-Bass.

Gairín, J. (2000). Cambio de cultura y organizaciones que aprenden. Educar, 27, 31-85.

Gairín, J. (2015) Las comunidades de práctica profesional. Creación, desarrollo y evaluación. Madrid:

Wolters Kluwer.

Gallager, T. (2013). Contact and context: Sharing education and building relationships in a divided society. Research papers in Education, 2, 1-18.

Giroux, H. (2016). Los profesores como intelectuales transformativos. Retrieved from http://otrasvoceseneducacion.org/archivos/124406

Gittell, J. H., Seidner, R., \& Wimbush, J. (2010). A relational model of how high-performance work systems work. Organization Science, 21(2), 490-506. https://doi.org/10.1287/orsc.1090.0446

Hargreaves, A., \& Fullan, M. (2014). Capital profesional. Transformar la enseñanza en cada escuela. Madrid, Spain: Morata.

Hargreaves, A., \& Shirley, D. (2012). The global fourth way: The quest for educational excellence. Thousand Oaks, CA, USA: Corwin Press.

Hildreth, P., \& Kimble, C. (2004). Knowledge Networks: Innovation through Communities of Practice. Oakland, CA, USA: Idea Group Publishing.

Horn, A., \& Marfán, J. (2010). Relación entre liderazgo educativo y desempeño escolar: Revisión de la investigación en Chile. Psicoperspectivas, Viña del Mar: Pontificia Universidad Católica de Valparaíso, 9(2), 82-104. 
Krichesky, G. J., \& Murillo, F. J. (2018). La colaboración docente como factor de aprendizaje y promotor de mejora. Un estudio de casos. Educación XXI, 21(1), 135-156. https://doi.org/10.5944/educxx1.20181

Leithwood, K. (2009). ¿Cómo liderar nuestras escuelas? Santiago, Chile: Fundación Chile/Fundación CAP.

León, R., Tejada, E., \& Yataco, M. (2014). Las organizaciones inteligentes. Industrial Data, 6(2), 082. https://doi.org/10.15381/idata.v6i2.6087

López-Vargas, B., \& Basto-Torrado, S. (2010). Desde las teorías implícitas a la docencia como práctica reflexiva. Educación y Educadores, 13(2),275-291. ISSN: 0123-1294. Disponible en: https://www.redalyc.org/articulo.oa?id=834/83416998007

Muijs, D., \& Rumyantseva, N. (2014). Coopetition in education: Collaborating in a competitive

environment. Journal of Educational Change, 15(1), 1-18. https://doi.org/10.1007/ Osterlind, S. J.

(1989). Constructing test items. Boston: Kluwer.

s10833-013-9223-8

Northouse, P. (2004). Leadership: Theory and practice. Thousand Oaks, CA, USA: Sage Publications.

OCDE. (2008). Improving School Leadership. Paris, France: OECD.

OCDE. (2009). Mejorar el liderazgo escolar. Herramientas de trabajo. Paris, France: OECD.

Osterlind, S. J. (1989). Constructing test items. Boston: Kluwer.

Parrilla, Á., Sierra, S., \& Fiuza, M. (2018). Lecciones esenciales sobre el trabajo en red inter-escolar. Profesorado, Revista de Currículum y Formación del Profesorado, 22(2), 51-69. Retrieved from https://recyt.fecyt.es/index.php/profesorado/article/view/66362

Pont, D., Nusche, D., \& Moorman, H. (2009). Mejorar el Liderazgo Escolar: Volumen I, políticas y prácticas. Paris, France: OECD.

Ramírez, C., García, E., \& Cruel, J. (2017). Gestión educativa y desarrollo social. Dominio de las Ciencias, 3(Extra 1), 378-390. Retrieved from https://dialnet.unirioja.es/servlet/articulo?codigo=6134923

Ríos, D., Maturana, D., Almonacid, C., Shink, H., \& Jaramillo, I. (2010). Innovaciones en centros educativos vulnerables: Liceos que optimizan la gestión para mejorar los aprendizajes de sus estudiantes. Revista Iberoamericana de Educación, 53(6), 1-12. https://doi.org/10.35362/rie5361708

Robinson, V., Hohepa, M., \& Lloyd, C. (2009). School Leadership and Student Outcomes: Identifying What Works and Why Best Evidence Synthesis. ACEL, 41, 1-28. Retrieved from https://www.educationcounts.govt.nz/publications/series/2515/60170

Ruay, R., \& Ferrada, J. (2017). La innovación educativa en una universidad regional chilena: La experiencia de un observatorio. Revista Boletín Redipe, 6(1), 37-49. Retrieved from https://revista.redipe.org/index.php/1/article/view/170

Rubia, F. (2018). Propuesta de niveles o estadios de complejidad organizativa en la innovación escolar. Revista digital de educación del FEAE-Aragón, 23(8). Retrieved from http://feae.eu/wpcontent/uploads/2018/03/Forum-Arag\%C3\%B3n-23.pdf\#page=30

Ruiz Olabuénaga, J. I. (2003) Metodología de la investigación cualitativa. Bilbao: Universidad de Deusto.

Santos, M. (2001). La escuela que aprende. Madrid, Spain: Morata.

Santos, M. A. S., Jover, G., Naval, C., Álvarez, J. L., \& Sotelino, A. (2017). Diseño y validación de un cuestionario sobre práctica docente y actitud del profesorado universitario hacia la innovación (Cupain). Educación XX1, 20(2), 39-71. https://doi.org/10.5944/educxx1.19031

Sierra, R. (2013). Técnicas de investigación social: teoría y ejercicios. (14a Ed.) Madrid: Paraninfo.

Schmelkes, S. (1998). Investigación educativa y gestión escolar: ¿Un binomio ejemplar? Caleidoscopio, 3, 21-30.

Silva, P., del Arco, I., \& Flores, Ò. (2018). La formación de directores escolares en Cataluña. Lecciones aprendidas a cinco años del decreto de dirección. Bordón. Revista de Pedagogía, 70(1), 109-124. https://doi.org/10.13042/Bordon.2017.49427

Tejada, J. (2008). Los agentes de la innovación en los Centros Educativos. Profesores, directivos y asesores. Granada, Spain: Aljibe. 
Tomás, M., Borrel, N., Castro, D., Feixas, M., Dolors, B., \& Fuentes, M. (2009). La cultura innovadora de las universidades. Barcelona, Spain: Octaedro.

Weinstein, J. (2009). Liderazgo directivo, asignatura pendiente en la Reforma Educativa Chilena. Estudios Sociales, Santiago de Chile, 117, 123-147.

Weinstein, J., \& Muñoz, G. (2012). ¿Qué sabemos de los directores de escuela en Chile? Santiago, Chile: Centro de Innovación en Educación de Fundación Chile; CEPPEUC.

Wrigley, T. (2007). Escuelas para la esperanza. Madrid, Spain: Morata. 